\title{
Trapped in a moral order
}

\section{Moral identity, positioning and reflexivity in stories of confrontation among Latin American teenage school girls in Madrid}

\author{
Adriana Patiño-Santos \\ University of Southampton, UK
}

This paper focuses on the forms of reflexivity that emerge in the conversational narratives of Latin American teenage school girls co-produced during sociolinguistic interviews, in a multicultural school in the centre of Madrid. The narratives about confrontation at school portray the girls' actions and ways of making sense of such behaviours, in the course of their migrant life trajectories. Understanding narratives as communicative repertoires (Rymes 2014) of an interactive and situated nature makes them suitable discursive spaces for revealing the moral identity constructed, and the moral order evoked in these narratives. Herein we analyse stories recounting conflicts with three different groups of opponents: female peers, teachers and parents. It is in recounting and evaluating moments of conflict that social actors call upon their systems of beliefs and values. The failure of the girls' secondary school and all the negative repercussions of such failure are central to the ethnographic circumstances in which their narratives are produced. Some attention will be given to the researcher's reflexivity, as a co-teller of the narratives gathered, but also in the interpretations made of the data in the light of expectations built up over time regarding the social actors' academic trajectories.

Keywords: reflexivity, conversational narrative, moral identity, Latin American girls, multilingual school

\section{Introduction}

Latin American migration in Spain refers to the significant arrival of people of Ecuadorian, Colombian, Peruvian and Argentinian backgrounds, during the early years, and subsequently Bolivians, Paraguayans and Venezuelans, triggered by Spain's participation in the globalised economy during the mid-1990s. Shared

AILA Review 29 (2016), 83-113. DOI 10.1075/aila.29.04pat 
language (Spanish in its different varieties), the Catholic faith, as well as historical and cultural links have been identified as the central factors that attracted Latin Americans to Spain. However, research has shown how these factors, coupled with the unskilled positions that Latin Americans often occupy in the Spanish labour market, far from integrating them, have tended to differentiate them as "the others", ethnically and socially (Block \& Corona 2016; Patiño-Santos 2015; Rettis 2004).

Within the processes of reception, school was considered a key site to promote social integration. However, studies and official statistics have shown how the students of Latin American backgrounds tend to fail and abandon the Spanish education system once they reach the age of 16 , the final year of compulsory education (Delpino 2008). Many aspects have been addressed, in educational, sociological and anthropological research, in order to understand the factors that force or encourage these students to enter the labour market early (Colectivo IOE 2012).

In this paper, I wish to give an account of this situation from the perspective of research on language, youth, mobility and reflexivity in late modernity, by taking an interpretivist position. I aim to explore the ways in which girls of Latin American backgrounds, members of various circles of friends, make sense of their negative attitudes and behaviour towards their Spanish school and the adults - teachers and parents - in their lives, and at the same time act out moral (and gender-based) identities in their conversational narratives produced in the field. Conversational Narratives (CNs hereafter) have been proven to be apposite tools to observe how social actors construct and negotiate identities, as well as rationales to justify their actions. Understanding CNs as social practices (De Fina \& Georgakopoulou 2008a) acknowledges their interactive and situated nature and makes them suitable discursive spaces for uncovering the logics of practice underpinning tellers' courses of action.

The data analysed were gathered in a longitudinal linguistic ethnography in Evangelista, a multicultural secondary school, carried out between 2003-04 and 2007-08. They represent situations and circulating discourses amongst and about girls of Latin American backgrounds that I have heard and collected repeatedly in subsequent linguistic ethnographies in Spanish multilingual schools where Latin Americans were concentrated (Codó \& Patiño-Santos 2014; Newman, PatiñoSantos \& Trenchs-Parera 2013; Patiño-Santos 2009). I have focused on stories of conflict produced by groups of 'stay at home girls' ("niñas de su casa"). These are girls controlled and restricted by the expectations and 'rules' of family life. This focus stems partly from the fact that conflict and resistance amongst Latino youths (as they are labelled in the US) have only been widely researched in males (e.g. Corona, Nussbaum \& Unamuno 2013 in Catalonia; Hurd 2004; Vigil 1988 in the US), or amongst female gang members (see Dietrich 1998; Mendoza-Denton 
2008), but also because girls represented the majority of students at this school in $2007 / 08$, the year in which it finally closed. Most of the boys had dropped out of the school by that year, so these girls represented those young people willing to complete their basic education.

I understand identity (and hence moral and gender identity) to be produced in social interaction, so the focus will be on the way social actors act out their (moral and gender) identity in interaction with others (Holmes \& Meyerhoff 2003). For that reason, the analysis of the narrative gathered in this context, which primarily deals with girls' conflictive relationships, will centre on the ways social actors give account of their own behaviour through positioning themselves (Davies \& Harré 1990) as moral authorities, subjects who feel empowered to 'mete out justice' single handedly over the course of their $\mathrm{CN}$ construction, based on a moral order (systems of beliefs). My presence at the school at different moments in the academic trajectory of these girls, as well as my knowledge of some of the situations depicted in their stories, established me as a co-producer of their stories. On later reflexion, I recognised that my personal background as an educated Colombian adult with my own academic and migratory trajectories led me to certain expectations, as is apparent over the course of the interviews with the young people.

The paper is organised as follows: the following section will present the site, method, data and the participants, leading to a detailed discussion of $\mathrm{CN}$ in ethnography, as the epistemological approach followed in this paper. The analysis will discuss narrative episodes of reflexivity in terms of the girls' identities and positionings as subjects with moral authority in stories of conflict at school and at home, and with different social actors - adults and peers. Girls' participation in conflictive situations and the ways in which they overcome such difficulties become central focuses for reflexivity regarding the courses of action reported by the protagonists. My participation as co-teller and elicitor of these narratives will also be addressed mainly in the excerpts devoted to conflict at home. The final section will be devoted to the discussion of the contradictions between the ideologies upheld in the girls' discourses and their actual behaviour as evidenced by many of their school trajectories.

\section{Site, method, and data}

My research carried out in Evangelista, a secondary school located in the centre of Madrid during 2003/04 and 2007/08 was part of a bigger research project (BF2003-04830) aimed at observing and documenting the ways in which secondary schools of the Madrid region were dealing with multilingualism and multiculturalism, as a new phenomenon at that time. Studying processes of school 
failure was not the original purpose, but it became my concern once I became a participant within this school. Even though I visited the school intermittently during that long period, I collected the data in two main stages, in 2003/04, observing class $2 \mathrm{~B}$, and in $2006 / 07$, class $4 \mathrm{~B}$, where most of those students who I had observed earlier were enrolled. In total, I collected 16 hours of classroom interaction in the Social Science and Language classes of the school years $2 \mathrm{~B}$ (in 2003/04) and 4B (2007/2008), as well as 8 hours of interviews with the managerial staff and the teachers of the observed subjects in both periods. Observations of the extracurricular activities were also gathered, as well as interviews with different circles of friends, five in the first period and six in the second.

Evangelista was one of the state schools of the city centre used by the Madrid local administration to concentrate students of migrant backgrounds, reserving the 'state funded' or religious schools for the children of Spanish backgrounds. Such a concentration started in 1999/2000. By 2003/04 Evangelista presented many ingredients of failure, as has been extensively reported in previous research (Patiño-Santos 2009, 2011a, 2011b; Martín Rojo 2010; Patiño-Santos 2014): the creation of a concentration of students mostly of Latin American backgrounds had precipitated the flight of children of Spanish backgrounds; there had been a reduction in staff members, half of whom were on temporary contracts while the other half were close to retirement, making it difficult to create a strong and unified pedagogical project. Meanwhile, the reduction in the number of students eventually became structurally and economically unsustainable. By the end of the school year 2006-2007, a building designed for 650 students hosted only 66 students throughout the four years of Compulsory Secondary Education (1-4 ESO). Locally, the confrontational interactions between the students and the teachers both within and outside the classroom, as well as mass media reporting of violence in the school, helped to destroy its reputation. The eventual fate of Evangelista demonstrated the shortcomings of the local government's policies of reception and schooling for newcomers.

From the very beginning, I focused on understanding and documenting the conflictive relationships between all the participants in the school, but the discrepancies between girls' discursive reflections on life, including the importance of school, and their actual behaviour were of particular interest to me. In our informal exchanges, these girls, aged between 13 and 17, would affirm the importance of school in achieving a better future, but then their thoughts would turn to life concerns that I, in thinking of my own academic trajectory at their age, considered more relevant to adults: issues such as being in love, getting married and having children. The issues that I observed and recorded, as well as their shared narratives, led me to question the naturalised behaviours apparent amongst the Latin American girls in this school. 
The Latin American girls in Evangelista were closely connected to their circles of friends. During 2003/4, my first long visit, I observed that most of the circles were wide and gender mixed. During the breaks, the 1st and 2nd year girls used to sit in groups around the playground to watch and cheer on the boys playing basketball or football. The oldest girls, who were in the $3 \mathrm{rd}$ and 4 th years, used to be in the cafeteria with their boyfriends or groups of friends, chatting and having coffee. In this first stage of my research, the girls dressed variously, but those with a 'sexy' hip hop aesthetic (tops, skinny trousers, leggings and hoodies) stood out. The school celebrations were animated by hip hop and reggaeton and dancers, in groups or couples, presented choreographies emulating Daddy Yankee (a famous singer)'s performances.

In 2006/7, the situation had changed dramatically. The visibly reduced number of students had obliged the school administration to close the cafeteria. The long breaks of 30 minutes had disappeared and were replaced by two fifteen-minute breaks. Most of the boys had dropped out of the school and you could see small groups of girls (typically in threes) wandering around the corridors, since students were not permitted to go outside the school to buy snacks. They were supposed to bring sandwiches from home, something that the girls disliked because they felt treated like primary school children. This new eating arrangement caused the students to organise themselves differently. Friends clubbed together into groups, which, though they might represent a mix of nationalities, were typically led by someone of Colombian or Ecuadorian background - these being the most widely represented nationalities in the school. The girls of Dominican, Moroccan or Filipino backgrounds, also represented at this school, stuck with one group or another, but Colombian and Ecuadorian girls rarely mixed with each other. They presented quite differently in public spaces. While Colombians paid extreme attention to their clothes, figures, hairstyles and make-up, Ecuadorians were much less 'showy', with less jewellery and without the tight clothes typical of the Colombians, who wore flashy leggings and 'sexy' tops.

For the purposes of this paper I focus on the CNs gathered from group interviews with two opposing circles of friends from $4 \mathrm{~B}$ that dealt with conflictive relationships between the female students and their peers, their teachers and their parents. The first circle, led by Lady (Colombian, 17), consisted of Isabel (16, born in Madrid of Filipino background and identified by her teachers as "The Filipino from $4 \mathrm{~B}^{\prime}$ ), and Jose (17), of Spanish origin. Jose was the only boy of Spanish origin in 4B. The members of the second circle were Carolina (16), the leader, Soraya (17) and Eugenia (16), of Ecuadorian backgrounds. The girls from the two circles used to confront each other, mostly verbally and especially in the final months. The only one who was born in Madrid was Isabel and the others had arrived in Madrid at secondary school age, none having lived there for more than three or 
four years. With the exception of Lady, the Ecuadorian girls had been assigned to Evangelista by the local education authority. Lady had spent one year in a previous school where she had felt bullied by her classmates. Having heard that Evangelista hosted a majority of Latin American students, she had asked to be transferred there in 2005. All these girls were portrayed by their teachers and themselves as "stayat-home" girls ("niñas de su casa"), so I was intrigued to discover the reasons they might give for fighting and how they dealt at home with the fact that they were failing the final year of their compulsory education.

\section{Reflexivity and moral identity positioning in narrative: A linguistic ethnographic approach}

Narrative has been understood as one of the most suitable discursive genres to study how identity and related issues, such as positioning, stance and categorisation are constructed and negotiated in daily life practices (De Fina \& Georgakopoulou 2011). Narrative analysis in sociolinguistics has always addressed certain aspects of "reflexivity", though never under that name, when considering the discursive and interactional devices and strategies that tellers use in order to fulfil certain communicative purposes. Thus, in seminal sociolinguistic approaches to narrative, Labov (1972) identified key components of the narrative (abstract, orientation, complicating action, resolution, evaluation and coda), giving evaluation a central role as the element of the narrative in which the teller suspends the action in a critical moment taken to present his/her views on the situation or the subjects depicted in the narration. It is in this evaluation that the reason for narrating certain events becomes explicit.

This initial attention to evaluative aspects of the narrative would become important within discursive studies that focussed on narrators' forms of 'positive' self-representation, and later on interactional approaches (Ochs \& Capps 2001; Georgakopoulou 2007, 2014) interested in narratives as sites for the local construction of identities and the negotiation of social realities (De Fina \& King 2011). Such studies have all shown, amongst many other issues, that through narrative the teller can accomplish particular communicative and argumentative purposes, such as lending credibility, resolving tensions and conflict (Schiffrin 1996), negotiating identities, justifying his/her behaviour and opinions (e.g. van Dijk 1993), displaying agency (Georgakopoulou 2006b) and defending moral positions (Relaño-Pastor \& De Fina 2005; Vásquez 2007).

The acknowledgement of narratives as interactional forms embedded in daily life conversations (Capps \& Ochs 2001; Georgakopoulou 2006b) or more recently in interviews (Thornborrow \& Coates 2005; De Fina and Georgakopoulou 2011; 
Kohler Riessman 2015) has opened up the possibility of exploring reflexivity in narratives beyond the interactional work of the speakers to include the analysis of the tellers' positionings on different communicative levels. Thus, narrators construct themselves as characters in relation to other characters in the depicted world, but also as co-tellers in the communicative situation wherein the narrative is being produced, and at the same time they position and align themselves in relation to other subjects and circulating discourses (or master narratives) beyond the immediate communicative situation (Bamberg \& Georgakopoulou 2008; Rymes 2001; Wortham 2001).

I understand CNs as defined by Ochs and Capps (2001): those interactionally embedded stories that do not necessarily follow a linear plot and that might evoke past, present or hypothetical future events. They are social activities co-constructed and negotiated by all the participants over the course of the interaction. Their heteroglossic nature allows the depiction of characters whose voices are included, making them powerful resources to express and negotiate moral positions in order to justify actions and choices, which might vary over the course of the narrative (e.g. Baynham 2003; Bucholtz 1999; De Fina 2003; Georgakopoulou 2007; Schiffrin 1996; Vásquez 2007). Such polyphony entails the enactment of multiple stances that may be in tension, or plain contradiction, within the various events portrayed during the narrative (Bakhtin 1984).

In analysing the narrative, I consider the ethnographical conditions in which it has been produced. This is beneficial in two regards: firstly, it reveals the discrepancy between what is affirmed by social actors in their communicative practices and the reality of their own trajectories. In this regard, Bourdieu's notion of habitus, understood as "the systems of durable, transposable dispositions, structured structures predisposed to function as structuring structures” (Bourdieu 1990: 53), becomes, as noted by Reay (2004) "a method for simultaneously analysing 'the experience of social agents and... the objective structures which make this experience possible' (Bourdieu 1988: 782)." (Reay 2004: 439). That is, habitus helps us to identify and unveil the rules, beliefs, and attitudes regarding what counts as being a "stay-at-home" girl coupled with the lack of importance that they attach to their lives as students, something that these girls have internalised and embodied.

At the same time, and even though this will not be the main focus of the paper, the notion of habitus allows the researcher to reflect upon her/his own participation as a researcher in the field at the moment of gathering the data (to explain the motivations for certain questions, for example). In my particular case, it also prompted a revisiting of the relationships first established with the other participants, nearly a decade ago, along with my own expectations directed towards the girls that I interviewed at that time (see Riessman 2015 for a discussion on revisiting data from a reflexive perspective). 


\section{Dealing with conflict in Evangelista}

The analysis focuses on the ways in which the girls draw on conversational storytelling in order to present themselves as moral authorities, and the resources they use to align themselves (or otherwise) with certain moral orders. I draw on analytical tools from $\mathrm{CN}$ (unexpected event, setting, response, consequence and evaluation ), but also on aspects such as voicing/dialogism (Bakhtin 1984), along with field notes that will allow me to contrast the moral order constructed in the storytelling, in which importance is given, for example, to academic attainment, with the girls' actual academic trajectories in the compulsory education system in Madrid. The contradictions between their positionings expressed discursively and what the students actually do will be relevant in discussing the habitus that is being reproduced by these young Latin American migrants in diaspora. Teachers' voices allowed me to widen the picture.

This section is divided into three parts. Each one presents one or two CNs in which the girls narrate and evaluate confrontational situations involving three groups of opponents: girls of rival cliques, their teachers and their parents.

\section{Fights between girls}

Fights between students in Evangelista were one of the marked disciplinary problems in the school. At the beginning of my research, in 2003/04, staff members reported problems of conflict between gangs of the boys in the school. The head teacher at that time recalled that students had been fighting at the main entrance and enumerated some of the given reasons, such as revenge between gangs. However, two or three years later, I started to realise that the most frequent fights were not between the boys but between the girls. Especially during the year 2005/6, when the upper floors of the building were empty due to the reduced number of the students. According to witnesses, the girls used to fight on the empty fourth floor, in the toilets, and in some areas of the playground that were not monitored by the teachers. They mainly fought close to the school entrance, after home time.

Excerpts 1 and 2 present, firstly, how students in general assessed the fights between girls as something anecdotal and fun, and secondly, how girls drew on narratives to construct themselves as moral authorities.

In Excerpt 1, we can observe three issues:

1. T. 1254 to 1258 clearly illustrates the dominant boys' positioning regarding the fights between girls. To my direct question about girls' fights, Jose replies laughing "too right", to indicate the futility of my question. In 1257 he states the impossibility of stopping the girls in a fight ("nobody gets involved"), a 
recurrent comment in the data that I gathered amongst boys talking about girls' fights. The laughs, the evasive responses given by Jose and all the boys' reactions on this topic, led me to understand that fights between girls were seen by some students in the school as something trivial, anecdotal or comic. The girls I interviewed, on the contrary, took them seriously as we shall observe.

2. In 1260, Lady decides to illustrate the point she has made in the previous turn about the fact that when there were more students at school, they used to fight more (an idea that concords with the principal's impression in 2003/04. In this example, we can observe the ways in which Lady positions herself as a moral authority in the narrative that she co-narrates with Isabel and Jose, by presenting herself as a person who is generally unaggressive, but can become violent when provoked. Thus, in 1260, she summarises the two fights in which she has participated. Since these are shared stories (Georgakopoulou 2007) with the circle, Jose intervenes to identify her opponent in the story. In 1265 the character "Susan" is introduced as the opponent, someone who is then reformulated by Isabel as having been "Carolina". In 1267 Lady summarises the fight, without presenting the unexpected event: "the thing is that she had a piercing here in her eyebrow / but that fight was short". In 1269 she describes the events chronologically: "I grabbed the eyebrow piercing and her hair", “... letting her know... I was gonna rip out the piercing”. Double voicing Carolina’s screams during the fight with a change in the tone of voice is a way to lend credibility and emotion to the narrated event (Ochs \& Capps 2001). Lady's move in voicing the opponent's screams, at the moment of defeat, to present evidence of her weakness is reinforced by the laughs of the co-tellers of the story. Turns 1263 and 1269 are used by Lady to portray herself as a moral authority, both reasonable and quiet, but at the same time a good fighter, able to plan fight tactics.

3. In the different interviews and conversations carried out during my fieldwork with the circles of friends and teachers, many reasons emerged for the girls to fight. Basically they mentioned a sort of "code" that should be respected: envy between girls was a cause of conflict that should be avoided, along with malicious gossiping (chismes), betrayal and the stealing of boyfriends. These motivations are similar to those documented by research on Latino girls in several sites in the USA (Dietrich 1998; Mendoza-Denton 2008) and seem to be normal at their age. The girls at Evangelista felt provoked by various triggers: suspicious or hostile looks and pushing in the corridors were frequently reported examples. I saw groups of girls looking at others to scrutinise the clothes they were wearing. In one of the breaks, a Colombian girl told me that the Ecuadorians wore "ropa del chino" (clothes from the discount Chinese shops), implying that their clothes were cheap imitations of poor quality. 
Excerpt 1. "On injustice"

Lady, Isabel, and Jose

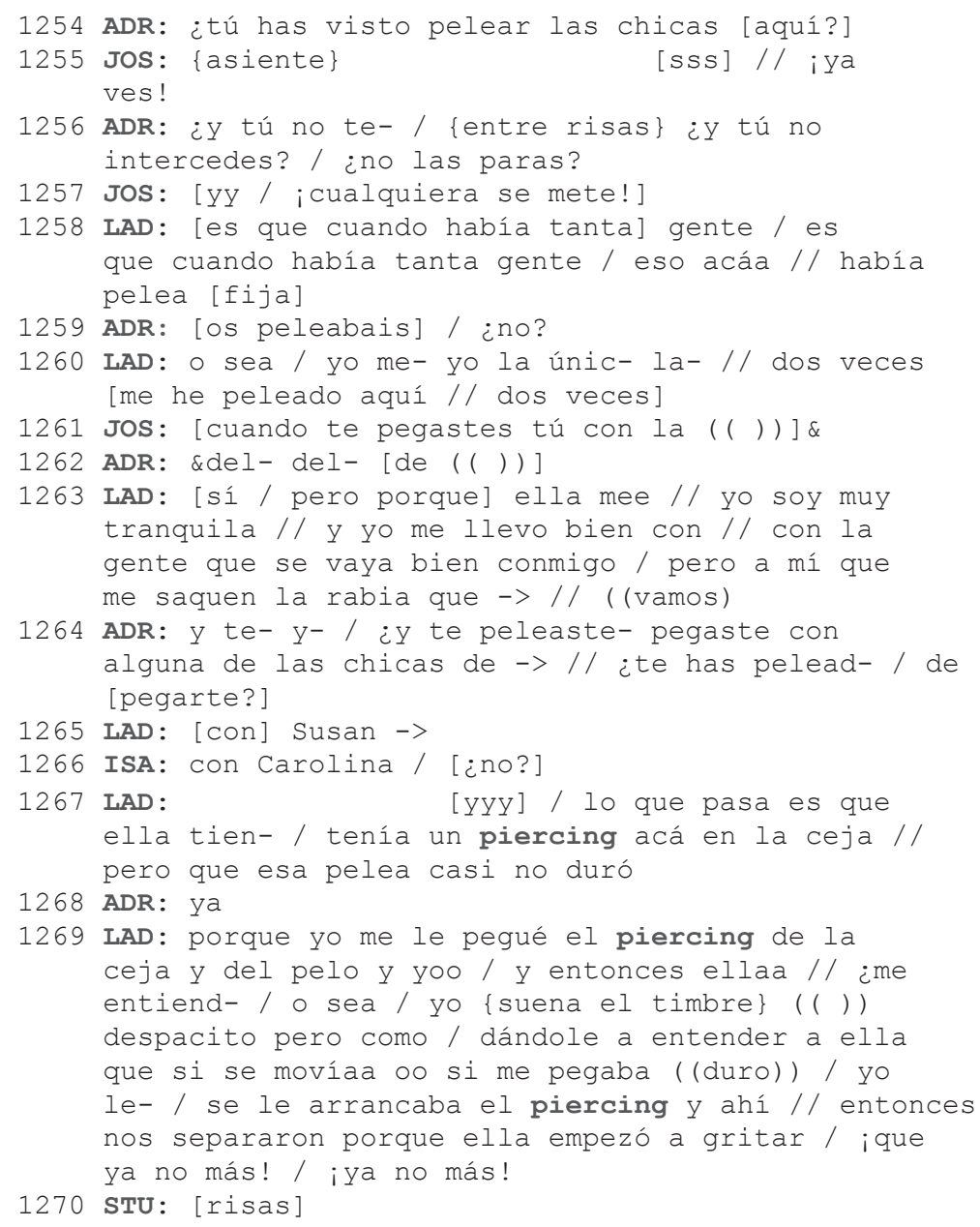

Some girls felt that others acted in a superior manner, refusing to socialise with certain classmates ("they think they're better than us" / "they fancy themselves"), something that often led to negative evaluations being voiced, and sometimes to physical fights. Leading on from the Excerpt 1, co-produced by Lady, Isabel and Jose, what follows introduces a second narrative in which Lady expands on her reasons for confronting other girls. Through this new story, Lady continues to portray herself as a morally coherent person and to some extent a moral leader:

After a few turns in which Jose, Lady and Isabel try to explain the reasons why class 4B is "divided", Jose in two turns (1119 and 1121) makes clear to me that the 


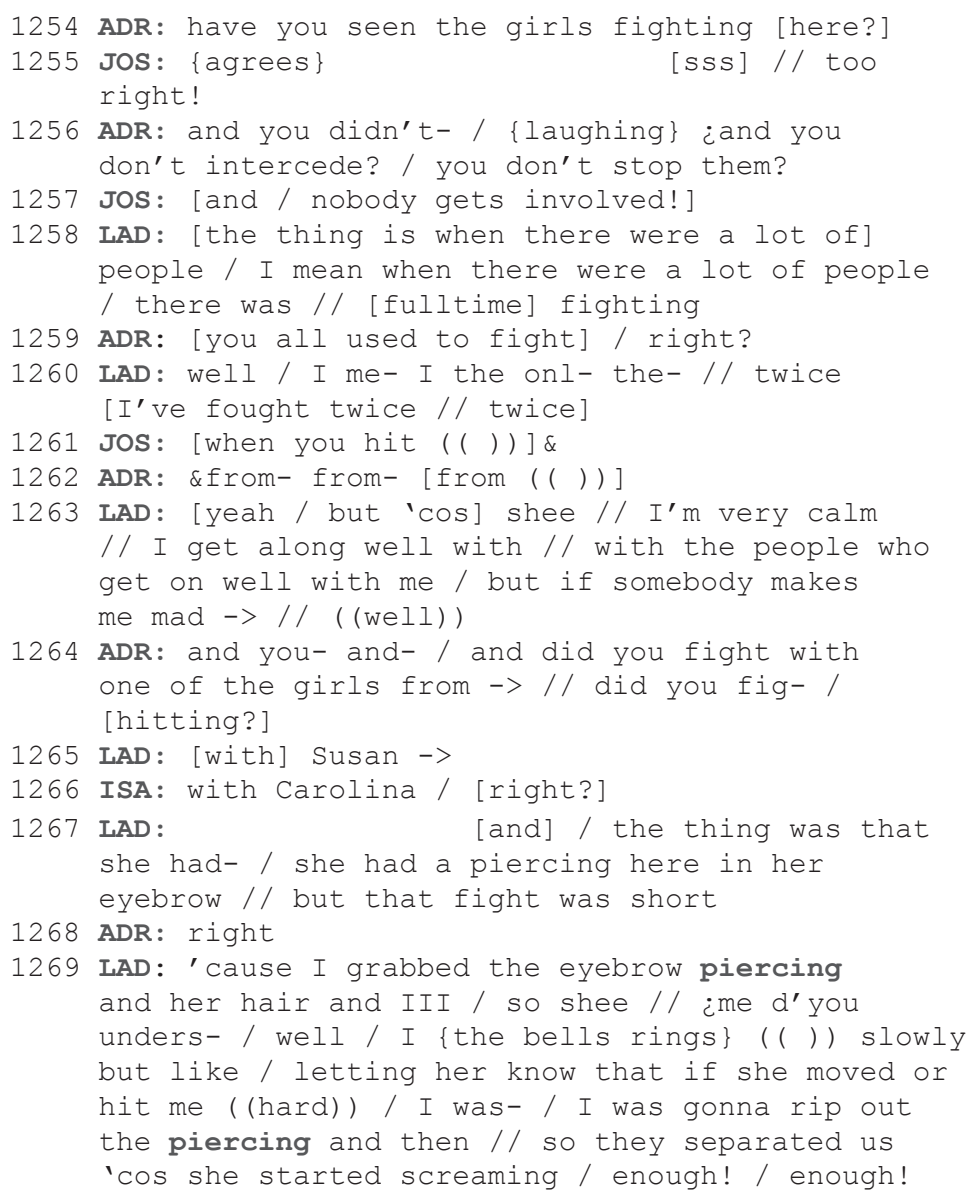

1268 ADR: right

1269 LAD: 'cause I grabbed the eyebrow piercing and her hair and III / so shee // ¿me d'you unders- / well / I the bells rings\} (( )) slowly but like / letting her know that if she moved or hit me ((hard)) / I was- / I was gonna rip out the piercing and then // so they separated us 'cos she started screaming / enough! / enough!

main cause of disagreements in the class is envy amongst the girls, something that he evaluates negatively in 1125 ("envy is very bad"). In 1123, Isabel starts to enumerate those who have a good relationship, excluding implicitly those who do not. In 1123 , she identifies the group by using the pronoun "we" assigning the predicate "get along well", and between 1126 and 1129 Lady, Isabel and Jose list the names of those who get on well: "all the boys, Isabel, Mónica, Deborah and Johanna".

Knowing the tense relationships with the group of Ecuadorian girls in the class (Carolina, Eugenia, Soraya and Susan, who had since left to join a Catholic school), in 1130 I ask about "the other girls". Finally, in 1140, Lady starts a CN in 


\section{Excerpt 2. "On lack of solidarity"}

\section{Lady, Isabel and Jose}

1118 ADR: [ipero tú] qué notas? // ¿por qué está dividido el curso?\&

1119 Jos: \&envidia

1120 ADR: envidia//entre: // ¿chicos y

[chicas?/( ( )) ]

1121 Jos: [entre chicas]

1122 ADR: =(( )) - entre chicas

1123 ISA: (no ( ( )) / es que entre todos [nosotros] nos llevamos bien / ( ( ) ) [(( )) $\left.)^{\circ}\right]$

1124 ADR: [ya ya ya // sí sí sí\&

1125 Jos: \&la envidia / que es muy mala

1126 LAD: o sea / son- son todos los chicos // y

1127 ISA: y yo // yy / Mónica / [que llegó hace poquito] / Deborah ahora\&

1128 Jos: \&y ((Johanna)) ahora / [y Deborah]

1129 LAD :

[y ((Johanna))] // pero

del [resto]

1130 ADR: [sí / yo veo] que estái- que es- / ¿esto está compacto? // noo bien // pero ya- las otras chicas no se integran

1131 ISA : $\left[(\mathrm{no})^{\circ}\right]$

1132 Jos: [ $\{$ chasquea la lengua\}]

1133 ADR: pero / ¿porque no estudiasteis juntos desde el principio? / [(( ))]

1134 LAD: [sí / [nosotros]

1135 Jos: [síii]

1136 LAD: =hemos estado varios años con ellas

1137 ADR: vosotras antes erais amigas // y os habéis peleado

1138 ISA: ( ( ( )) $)^{\circ} \&$

1139 ADR: \&esta chica / es que ->

1140 LAD: o sea / no es que nos hayamos peleado / sino quee // hay cosas que ellas hacen / que a mí no me gustan

1141 ADR: ya ya ya

1142 LAD: por ejemplo / lo que pasaba con Deborah // Deborah la que llegó nueva // y Deborah al principio / pues como ella también es ecuatoriana se- se iba con ellas\&

1143 ISA: \&(claro) ${ }^{\circ}$

1144 LAD: \{tose\} pues ellas qué hacían / ellas // entre las cuatro / se unían entre ellas / y a Deborah la dejaban aparte // y ellas salían y se iban / y Deborah por detrás // persiguiéndolas por todos los lados // y son entre ellas / y son como hablando en secretos entre ellas / y a uno lo dejan como así / como [aparte]

1145 ADR: [yaa]

1146 LAD: entonces eso a mí no me gusta / y -> 
1118 ADR: [but what] do you notice? // why is the class divided?\&

1119 Jos : \&envy

1120 ADR: envy//between: // boys and [girls?/(( ))]

1121 Jos: [between girls]

1122 ADR: = ( ( )) - between girls

1123 ISA: (no (( )) / it's that [we] all get along well together/ ( ( )) [(( )) $\left.)^{\circ}\right]$

1124 ADR: [right right right // yes yes yes\&

1125 Jos: \&envy / is very bad

1126 LAD: that is / they're- they're all the boys // and

1127 ISA: and me // and / Mónica / [who came very recently] / Deborah now\&

1128 Jos: \&y ((Johanna)) now / [and Deborah]

1129 LAD: [and

((Johanna)) ] // but [the others]

1130 ADR: [yes / I see] you guys ar- what is it- / are tight? // noo well // but then- the other girls don't join in

1131 ISA: $\left[(\mathrm{no})^{\circ}\right]$

1132 Jos: [\{clicks his tongue $\}]$

1133 ADR: why / because you didn't study from the beginning together? / [(( ))]

1134 LAD: [yes / [we]

1135 Jos: [yees]

1136 LAD: =we've been several years with them

1137 ADR: you were friends in the past // and you've fought

1138 ISA: ( ( ( )) $)^{\circ} \&$

1139 ADR: \&this girl / it's that $\rightarrow$

1140 LAD: well / it's not that we've fought / but thaat // there are things they do / that I don't like

1141 ADR: right right right

1142 LAD: for example / what happened with Deborah // Deborah the new girl // and Deborah at the beginning / well since she's Ecuadorian too she- she went with them\&

1143 ISA: \& (sure) ${ }^{\circ}$

1144 LAD: \{coughs\} well what did they do / they // between the four of them / they stuck together / and left Deborah out // and they would walk off with Deborah following along behind wherever they went // and they just keep it to themselves // and they were like talking in secret together / and leaving you out / like [separate]

1145 ADR: [riight]

1146 LAD: so I don't like that / and -> 
which she summarises and evaluates her relationship with her opponents: "it's not that we've fought / but that there are things they do that I don't like". The CN containing this evaluation is narrated in several turns. In 1142, she introduces the character of "Deborah", identified as an Ecuadorian newcomer. Her ethnicity is brought up to explain why Deborah chose to join the group of four other Ecuadorians. This explanation is supported by Isabel ("of course"), who becomes a co-narrator in 1143. In 1144 Lady presents the behaviour of these four Ecuadorians towards Deborah. I show understanding of the situation in 1145, which leads Lady to conclude the narrative by reiterating her opinion and justifying her fight with Carolina recounted in Excerpt 1: "so, I don't like that".

From this $\mathrm{CN}$ we can understand the behaviour of the group of four Ecuadorians of whom Lady and her co-tellers do not approve morally: they form an exclusive clique, and when somebody such as the newly arrived Deborah needs them, they ignore her. By drawing attention to the behaviour of these girls, Lady is signalling what she considers to be 'correct' behaviour: newcomers should be integrated; secret conversations are not allowed; excluding classmates is not acceptable. Lady thus presents a strong argument for having picked a fight with some of them in the past. In such cases, she feels that justice is on her side.

This first section has shown the ways in which the girls portrayed themselves as moral authorities in the school setting, in opposition to certain (disloyal) peers. The next section stays in the setting of the school but introduces a new group of opponents, the teachers, including some of the ways they confront them, and their reflections upon their own behaviour.

\section{Confronting the teachers}

Reflexivity in the form of moral positioning dominates in the group CNs when the circles of friends narrate conflictive situations with their teachers. The moral ethos of the group, led by the girls, emerges in the ways in which they characterise themselves and their teachers as main characters in the narrated events, as well as in their evaluations of their teachers' behaviour under the conflictive circumstances. The following story, co-narrated by Carolina, Eugenia and Soraya from $4 \mathrm{~B}$, illustrates the moral positioning constructed and the moral orders towards which they orientate themselves. Their teacher is constructed in opposition to their own behaviour and system of values:

Given the fact that conflicts between students and teachers were one of the dominant practices in this school, I decided to ask about those situations. In the final years of Evangelista, most of the students were girls, and conflicts between teachers and girls happened more regularly than between teachers and boys or the 
group as a whole (Patiño-Santos 2009). In this example, in response to my question in 325 about whether they had had moments of conflict with any teacher, Eugenia, in two turns, explains that there had been no such conflicts since year 3. However, my reformulated question in T. 329, triggers in Carolina a memory of two conflictive situations with their tutor, at the beginning of the current school year. Carolina initiates her own story, by offering the setting (time and main characters) in different turns: "this year with the teacher / with the tutor", and two turns later, she specifies that the two of them, Carolina and Soraya, had had a disagreement with their tutor, constructing herself and her friend as characters in the story. I, as an adult, concluded that the girls "had done something", to which the girls immediately react in order to clarify that it was the teacher's fault. Regardless of the apparent facts of the situation, we then have two co-narrated CNs in which the three girls portray the teacher as unfair, in opposition to themselves as fair and honest, as we will observe.

In T. 338 Soraya tells her own related short story in one turn. She initiates a CN where she is co-protagonist of the conflict, by summarising the teacher's behaviour: "she started shouting and I'cos we're not allowed to shout / and sometimes when it's not our fault". She starts with the resolution of the conflict "the other day she sent me out of the class" and goes on to present the main events leading up to this in chronological order: “but I didn't say anything / I didn't do anything / I was like talking to her (Carolina) / and she asked me a question and I answered". Soraya presents herself as having acted in a passive way, as a victim of circumstances, by indicating that she was just answering Carolina. The teacher's response is double voiced, "Out of the classroom!", imitating the force of the shout in a demonstration. In T. 339 Carolina intervenes to close the narrative by double-voicing Soraya's answer: "OK I'm off".

Two turns later, Carolina self-selects to tell her own conflict story with the same tutor. The fact that these experiences are shared by the members of the circle allows them to take the floor in order to complete or co-narrate anecdotes about things that have happened to their friends, or in which they were secondary characters, as we observed in the conclusion to the narrative told by Soraya previously. In this new case, Carolina forgets a detail in the anecdote that she wants to use in order to illustrate her teacher's behaviour, so Eugenia self-selects to co-construct the unexpected event ("'cos of the mobile"). Soraya takes the floor to contradict Eugenia, but Carolina aligns herself with the story initiated by Eugenia. So in T. 344, Carolina explains her story.

Carolina starts her narration by presenting the unexpected event ("they called me from 97") giving the reasons that she had to answer a phone call during the class. This reasoning allows her to construct herself as somebody caring and 


\section{Excerpt 3. "The disagreeable tutor"}

\section{Carolina, Eugenia y Soraya}

325 ADR: pero yo quiero si habéis tenido con profesores algún tipo de $\rightarrow /=$

326 EUG: en tercero

327 ADR: =algún tipo de cosa en la que:

328 EUG: ya no / de ahí en adelante no

329 ADR: no habéis vuelto a tener con profesores de

330 CAR: esta / este año con / en los primeros días con la profe- / con la tutora

331 SOR: ah sí / con la tutora

332 CAR: ella y yo (refiriéndose a Soraya)/ las dos (risa)

333 ADR: vosotras / qué le hacíais?

334 CAR y SOR: no! NO i / es que ella

335 CAR: fue porque ella:

336 SOR: ella era antipática

337 EUG: es que

338 SOR: ella / ella comenzaba a gritar y yo a no dejarnos gritar a nosotras / y a veces así sin tener culpa /y comenzaba- / si el otro día me mandó a mi fuera de clase / bueno al principio y no / por no hacer- / pero no dije nada / no hice nada / estaba era hablando con ella (Carolina) /y me hizo una pregunta y yo le respondí / ifuera de clase! / y no y no ni le respondí ni gritando ni nada / si no así / ifuera de clase!/

339 CAR: bueno me voy /

340 ADR: ya

341 CAR: a mí / por qué era que me mandó $\uparrow /$ no me acuerdo

342 EUG: (por el móvil / por el móvil)

343 SOR: no / no / no

344 CAR: ah sí / fue porque me llamaron al móvil y me llamaron del 97 y a mi cuando me llaman del 97 es porque es mi tía de Zaragoza y si me llama a esa hora es porque le pasa algo / entonces/ yo dije / mi tía / yy si yo le decía que era mi tía / no me iba a dejar salir / entonces yo le dije es mi papá / ipuedo salir?/ me dice no / que están prohibidas / ya bueno me dejó salir / no me hizo casi problema y me dejó salir / salí y entré y me dice ee / bueno / ahí fue culpa mía / me dice ee 
325 ADR: but I'd like to know if you and the teachers have had any sort of $\rightarrow /=$

326 EUG: in year 3

327 ADR: =any sort of thing in which you:

328 EUG: not anymore / since then no

329 ADR: you and the teachers haven't had any other

330 CAR: this / this year with / during the first few days with the teacher- / with the tutor

331 SOR: ah yes / with the tutor

332 CAR: me and her (pointing to soraya)/ both of us (laugh)

333 ADR: you two / what did you do to her?

334 CAR y SOR: no! NO i / it was her

335 CAR: it was ' COS she:

336 SOR: she was horrible

337 EUG: it was ' cos

338 SOR: she / she started shouting and I'cos we're not allowed to shout / and sometimes when it's not our fault /and she started- / yes the other day she sent me out of the class/ well at the beginning and not / for not doing- / but I didn't say anything / I didn't do anything / I was like talking to her (Carolina) / and she asked me a question and I answered / out of the class! / and I didn't I didn't reply by shouting or anything / and it was / out of the class!

339 CAR: OK I'm off /

340 ADR: right

341 CAR: with me / why was it she sent me^/ I can't remember

342 EUG: ('cos of the mobile / ' cos of the mobile) ${ }^{\circ}$

343 SOR: no / no / no

344 CAR: ah yes / it was 'cos they called me on the mobile and they called me from 97 and when they call me from 97 it's 'cos it's my auntie from Zaragoza and if she rings at that time it's 'cos something's happened to her / so I said / my auntie / and and if I said it was my auntie / she wouldn't let me go out / so I told her it's my dad / can I go out?/ she says no / they're not allowed / anyway she let me out / she didn't make much fuss and she let me out / I went out and came back and she says ee / well / that was my fault / she said ee 
Excerpt 3. (continued)

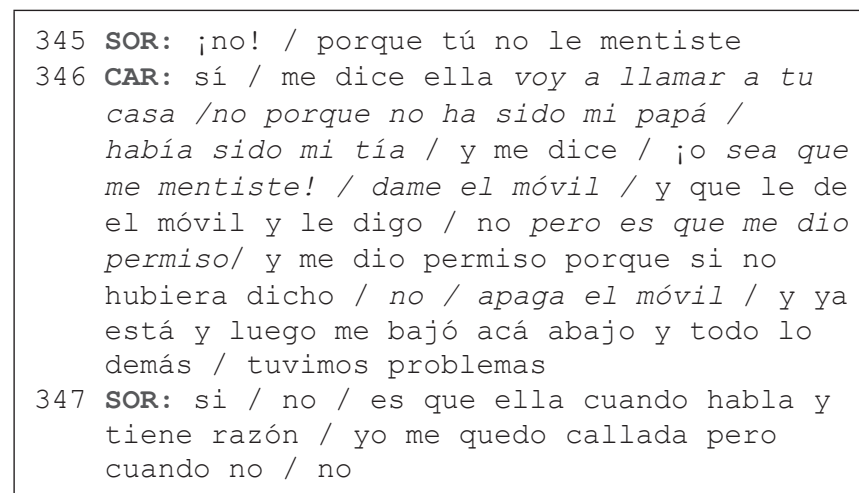

concerned about her family, doing the 'right' thing. We can also observe how she reflects upon her own behaviour, when she presents the moral dilemma she had to face, either telling the truth or lying. She constructs herself as a moral agent who needed to make a decision in the face of a delicate situation. Even though, in the first part of the episode, she decides to lie by saying that it was her father ringing, in order to get permission to answer the call, once she came back into the class, the teacher inexplicably starts to tell her off. Then, displaying a reflexive action as a character in the narrated world, Carolina explains her decision to change her story and tell the truth to avoid her parents becoming involved should the teacher ring her home. As a consequence of her admission, the teacher accuses her of having lied and confiscates the phone. Carolina was sent to the head teacher on the administrative floor below ("she sent me down here"). The teacher is thus portrayed as somebody contradictory since she initially gave her permission to answer the phone but then she tells her off and accuses her of lying.

This second episode is constructed through important resources such as double-voicing. Carolina performs her dispute with the teacher, which lends emotion and credibility to the story as reported in previous research on conflictive relations (Carranza 1993). The two voices are presented in a contrastive way: while the teacher's voice is represented as authoritarian by adopting a loud voice and direct style, Carolina's voice is quiet and her responses supported by reasons to behave in the way she did. Soraya closes the narrative by evaluating her own behaviour in response to their teacher's actions, based on the way in which they understand the moral principle of justice: "it's like with her when she says something and she's right / I keep my mouth shut but when she's not / I don't”. This conclusion strengthens the point that the three girls portray themselves as reflexive by being 


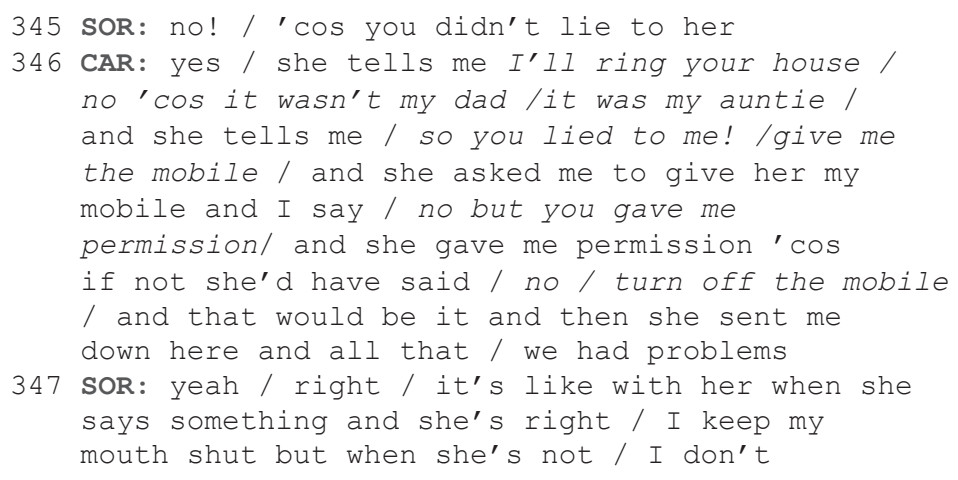

aware of what is good/bad, and by showing that they are able to adapt to the circumstances. Carolina did not want to lie, but once she decides to tell the truth, as noted by Soraya in T345, she is punished. Table 1 summarises the portrayals of the tutor and the girls, who are constructed in opposition.

By describing their teacher's behaviour as unfair and contradictory, the girls construct themselves in opposition as fair, reasonable, supportive - a set of moral values that, in the end, are used by the girls to justify their own behaviour within the stories they tell.

So far, I have presented the girls' confrontational relations at school with peers and teachers. They depict themselves as moral agents who respond to morally questionable subjects (unfair, dishonest, unreliable, etc.) directly. The actions portrayed in their narratives as well as the self-justifications construct an image of reflective agents able to discern between right and wrong. The next section will look at conflict at home, a setting strongly linked to the school.

Table 1. Girls' portrayals of the tutor and themselves.

\begin{tabular}{ll}
\hline The tutor & Soraya and Carolina \\
\hline Disagreeable & $\begin{array}{l}\text { Friendly and caring (with family and } \\
\text { friends) } \\
\text { Calm and reasonable }\end{array}$ \\
$\begin{array}{ll}\text { Unfair (she shouted at them for no apparent } \\
\text { reason) }\end{array}$ & $\begin{array}{l}\text { Contradictory (she gives Carolina permission } \\
\text { to go out and then reprimands her) }\end{array}$ \\
$\begin{array}{l}\text { Initiates conflicts } \\
\text { truth }\end{array}$ \\
\hline
\end{tabular}




\section{Conflict at home}

Reflexivity through the construction of the self as a moral authority was also a feature of their reported behaviour at home and of their relationships with parents and family, in general. Since the main topic of our interviews was their academic performance during the first two terms of the school year 2006/7 I framed most of the questions around trying to understand how they reconciled their low achievements with their lives as stay-at-home girls and their own expectations of the future.

One of the 15 interviewees, Isabel, a participant in Extracts 1 and 2, was passing the year comfortably, while, the rest were struggling with at least four subjects. Carolina and Soraya were failing four. They had failed seven in the first term, so they felt they were improving, and Eugenia had failed six subjects. Failing subjects was seen by the students as a normal practice, along with the previously mentioned situation of repeating a year. For that reason, I wanted to explore the impact of such poor results on what happened at home.

Excerpts 4 and 5 present a group $\mathrm{CN}$ that will reach an important resolution at the end of Excerpt 5.

The three girls co-construct a shared narrative by co-telling individual narratives. Each $\mathrm{CN}$ offers important aspects for our analysis of the construction of a moral positioning. Issues on methodological reflexivity and my role in the field are also relevant in this example. The co-narrated story is initiated in answer to my question in T. 457 about the support that these students receive from their parents. This question will frame the answer given by each girl, which is a shared master narrative (Bamberg \& Georgakopoulou 2008): 'we are the hope of our families because our siblings have disappointed our parents', something materialised in three individual stories:

The first story is told by Carolina, as one of the protagonists; after Carolina and Soraya confirm the support they receive at home in response to my question (T. 458 and 459), Carolina decides to expand her answer and in T.461 introduces a short story where she presents the characters of her family setting: herself, "my father" and "five brothers". The actions with which the siblings are portrayed show how the oldest three male siblings had dropped out of school, something confirmed by Eugenia, as Carolina's co-narrator. In 465, Carolina evaluates her own situation by emphasising the fact that she is the only girl in her family. Soraya, in 466 , takes the floor and by using a free indirect style, enacts Carolina's father's voice "his pride", something that I reformulate as "the apple of his eye". Carolina confirms my interpretation.

The second individual story that recreates the master shared narrative starts when I select Eugenia in T470. She feels invited to narrate her own family story 
"my mum has two girls / one has already let her down and now I / I have to turn out right". At this point, Eugenia introduces the 'disappointment' event as an anticipation of the resolution of the story that we will not meet until the end of Excerpt 5. This unresolved narrative thread (the nature of the disappointment) creates some sort of suspense in the narration and motivates Eugenia to present herself as an agent who must escape her sister's (so far mysterious) fate. When I inquire directly about her situation, Eugenia expresses her uncertainly with the words: “I mean I don't know what to do". However, Carolina's reflection in 474 summarises their shared situation "I think that in all our three cases it's the same that we have to be the pride of our families".

The final individual story is prompted by Carolina's explicit evaluation of their shared situation in 474 . Soraya takes the turn to tell her family story, where again, the characters, her four older siblings, have dropped out of school, so it is only the two younger ones who are still at school. As in Carolina's case, Soraya concludes her story by echoing their shared master narrative "so my mum has all her hopes pinned on me".

These three interconnected stories and the evaluations stated by the girls reveal their reflexivity regarding what is expected of them as school girls: they all present themselves as aware of the consequences of their behaviour, they feel a sense of responsibility and a pressure not to disappoint their parents. The behaviour of their siblings is evaluated morally as something incorrect and an example that they are expected not to follow. Being the pride of the family represents a pressure upon them, as we can observe from Eugenia's worries. She is failing the school year, but she is aware that she must not turn out as her sister did.

A final aspect of this narrative is that it reveals how I can use storytelling to assess my own participation in the field. In terms of methodological reflexivity, storytelling characterises some of the roles I played and the ways I was perceived. In this particular example, Carolina reports, in T. 463, on John, one of her brothers who dropped out of school. She reminds me that I had met John two years earlier, the first time I came to the school and conducted various academic activities with year 2B. Carolina and her brother were part of that group. It was interesting that Carolina brought up our previous time spent together and I understood her comment as a way to establish a level of trust between us and to express a degree of familiarity. However, the analysis in Excerpt 5 will show that the girls identified me as one of the adults in the school. The shared narrative, even though it presented a high level of reflexivity over their sense of moral commitment towards their parents, was also being produced for me as an adult who might expect a degree of reflexivity as an index of maturity from teenagers. I will show this in the final discussion, when I bring together all the pieces of information that will allow me to triangulate and interpret my data. 
Excerpt 4. Moral duties as "good" girls.

Carolina, Eugenia and Soraya

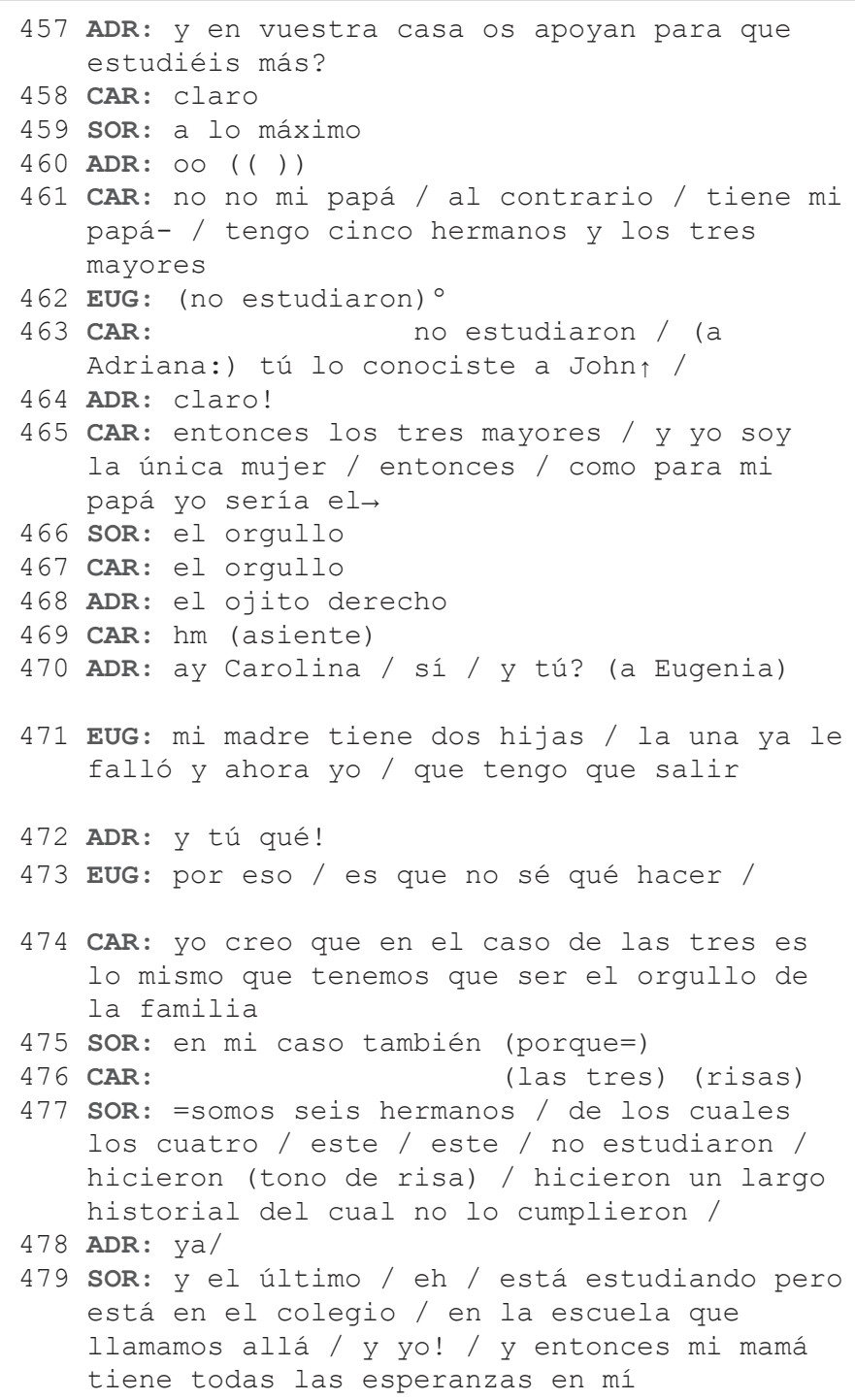

This example presents two important forms of reflexivity. One, regarding the young girls in the interview situation, in which they construct themselves as morally orientated towards the values that they believe adults (parents, teachers and myself) expect of them, and a second form of reflexivity is related to my own position as researcher and the nature of my involvement within the field. 
457 ADR: and do they support you at home to study more?

458 CAR: of course

459 SOR: totally

460 ADR: o० ( ( ))

461 CAR: no no my dad / on the contrary / my dad has- / I've got five siblings and the three oldest

462 EUG: (didn't study) ${ }^{\circ}$

463 CAR: didn't study / (to

Adriana:) you met John $\uparrow$ /

464 ADR: that's right!

465 CAR: so the three oldest / and I'm the only girl/ so / for my dad I'd be the $\rightarrow$

466 SOR: his pride

467 CAR: his pride

468 ADR: the apple of his eye

469 CAR: hmm (nods)

470 ADR: ay Carolina / yeah / and you? (to Eugenia)

471 EUG: my mum has two girls / one has already let her down and now I / I have to turn out right

472 ADR: and what about you!

473 EUG: that's the thing / I mean I don't know what to do /

474 CAR: I think that in all our three cases it's the same that we have to be the pride of our families

475 SOR: in my case too (because=)

476 CAR: (the three) (laughter)

477 SOR: =we are six children /out which four / this one / this one / they didn't study / they had (laughing) / they had a long history of let-downs /

478 ADR: well/

479 SOR: and the youngest / eh / he's studying but he's at school/ he's at the primary school as we call it there / and me! / so my mum has all her hopes pinned on me

The girls' reflective repertoires performed in CNs show that they are aware of the importance of passing the final year of compulsory school. Carolina's evaluation in T. 378, "look Miss / if we wanted / we could pass easily / pass the fourth year" appears to be a voicing of what her parents and teachers have no doubt told her many times. However, she goes on "but the thing is we can't be bothered / we just 
Excerpt 5. "On moral duties"

Carolina, Eugenia and Soraya

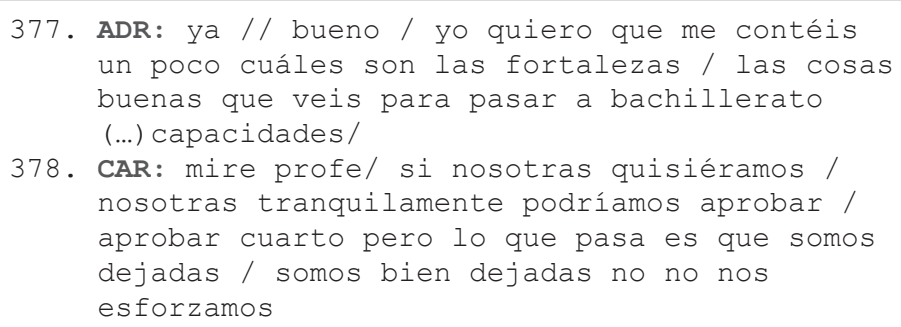

378. CAR: mire profe/ si nosotras quisiéramos / nosotras tranquilamente podríamos aprobar / aprobar cuarto pero lo que pasa es que somos dejadas / somos bien dejadas no no nos esforzamos

379. ADR: pero por qué es?

380. (Risas)

381. CAR: porque si / porque somos dadas a que más / damos prioridad a otras cosas / yo por ejemplo / yo doy prioridad a otras cosas

382. ADR: dime algo a lo que le des prioridad

383. CAR: al messenger

384. Risas

385. ADR: al messenger

386. CAR: entonces / cosas así / y es porque nosotras no queremos / porque si nosotras quisiéramos pasaríamos sin ningún problema

387. ADR: es que yo lo sé / yo lo sé si si

388. CAR: y entonces. $\rightarrow$

389. ADR: (...) o sea que si os ponéis / 10 podéis hacer / y tú / Eugenia

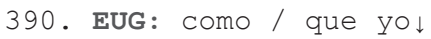

391. ADR: porque tú no sabes todavía qué quieres estudiar $\uparrow$

392. EUG: yo / no

393. ADR: y si no encuentras qué estudiar de aquí a julio qué haces?

394. EUG. no lo sé / no tengo nada claro

395. SOR: \&hacer lo que hizo la hermana

396. ADR: hacer lo que hizo tu hermana? / qué hizo tu hermana?

397. (risas)

398. EUG: se fue a Ecuador / vino embara- / y todo eso (risas) / y ahora está estudiando en la tarde (risas) / está estudiando en la tarde//

don't care and don't make the effort", expanded in 386 "it's because we don't want to", thus summarising the reflection made by all the students interviewed and observed: laziness and distractions were at the root of their academic problems and poor results. Again we see how in their actions they show no real intention of fulfilling the 'borrowed' values they appear to uphold discursively. They display 
377 ADR: yeah // well / I'd like you to tell me a bit about your strengths / the good things

you have to go on to the baccalaureate / (...) skills /

378 CAR: look Miss/ if we wanted / we could pass easily / pass the fourth year but the thing is we can't be bothered / we just don't care and don't make the effort

379 ADR: but why?

380 (laughter)

381 CAR: because that's how it is / we're into other stuff / we prioritise other things / me for example / I prioritise other things

382 ADR: tell me something you prioritise

383 CAR: messenger

384 (laughter)

385 ADR: messenger

386 CAR: so / things like that / and it's because we're not interested / because if we wanted we'd pass without a problem

387 ADR: I know that / I know that $\downarrow$

$388 \mathrm{CAR}:$ and $\mathrm{sO} \rightarrow$

389 ADR: (...) that means that if you try / you can do it / and you / Eugenia

390 EUG: what d'you mean / me $\downarrow$

391 ADR: because you don't know what you want to study yet $\uparrow$

392 EUG: me / no

393 ADR: and if you don't find something to study between now and July what will you do?

394 EUG. I don't know / nothing's clear to me

395 SOR: \&do what her sister did

396 ADR: do what her sister did? / what did she do?

397 (laughter)

398 EUG: she left for Ecuador / she came back pregn- / and all that (laughter) / and now sh goes to evening classes (laughter) / she goes to evening classes//

reflexivity through a common awareness that lack of effort will cause them to fail. However, they blame boredom for their lack of application, along with the fact that most of their classmates dropped out of school on turning 16, without having completed their ESO qualification, as explained in previous publications (Patiño 2011a, 2011b). 
In T. 387, I show the high expectations I had of Carolina, based on observation of her academic potential three years previously. It was only in subsequent analysis of the data that I was able to acknowledge reflexively that the girls interviewed were responding discursively to the 'adult' expectations I had revealed, in the same way that they responded to those of their parents and teachers.

Eugenia's indecision, narrated in different turns presents a co-narrated epilogue that is initiated by my question in T. 389. Eugenia explains that she does not know. Soraya then takes the floor in T. 389 to bring to the communicative scene the resolution of the incomplete $\mathrm{CN}$ initiated in T. 471 Excerpt 4 ("my mum has two girls / one has already let her down and now I / I have to turn out right"). Their embarrassed laughter in response to my question seeking clarification in 396 indicates that they evaluate Eugenia's sister's behaviour as something not morally correct. Eugenia takes the floor and in T. 398 she resolves the suspense by narrating her sister's story in chronological order: her sister went to Ecuador and came back pregnant. She goes to evening classes.

Attending evening classes emerges as a recurrent theme in the interviews and informal conversations with the students in Evangelista, characterised as some sort of punishment/penance for those who drop out of school and then realise that they need to complete, at least the Secondary Compulsory Education. Thus, for example, John, Carolina's brother introduced in Excerpt 4, ended up attending evening classes after dropping-out of mainstream education to work in construction.

My final concern about the girls' poor academic results focussed on their parents' reactions. Of the 14 girls interviewed, six reported being controlled at home. None of them reported physical punishment but rather the types of control listed by Carolina: prohibition of the use of their mobile phones, constraints on their ability to socialise with friends and peers. The girls found ways to sidestep the prohibitions, by 'skiving off' school or indeed by confronting their parents directly in the words of Carolina and Deborah in two different interviews: "being rebels".

\section{Discussion and concluding remarks}

The study of young migrants' reflexivity, as manifested in their CNs produced in interviews, has led us to observe the ways in which a group of girls of Latin American backgrounds, enrolled in the Spanish education system, make sense of the conventionalised social and semiotic norms in which they are immersed, as well as the ways in which they "position themselves and others with respect to such conventions and to the social meanings / models attached to them" (PérezMilans 2016). 
The CNs on conflict with different social actors of their immediate environments, school and home, produced by Latin American 'stay-at-home' girls, became apposite communicative resources for reflection on their own and others' behaviours at moments of tension and on the ways in which they have addressed such difficult moments. They portray themselves as reflexive subjects able to answer the central questions that social actors in late modernity ask themselves: "What to do?", "How to act", "Who to be" (Giddens 1991). In this regard, they position themselves as moral authorities who take justice into their own hands, exacting punishments, sanctioning others' courses of actions and discursively constructing a moral order with which they align themselves. As moral authorities, these girls vest themselves with the legitimacy necessary to evaluate situations and others' behaviour. In sum, the narrated events and the relationships between characters, including themselves, depict them as reflexive actors aware of what is or is not acceptable in the different situations narrated.

However, the relationship between the reflexivity displayed in the CNs and the unhappy ending (from my own point of view as a female, educated Latin American adult), with their incomplete academic trajectories, needs further discussion. I certainly believe that these girls were trapped in a moral and social order that they decided not to challenge, but to reproduce. Even though, as pointed out by Pérez-Milans (2016), current theories on reflexivity in sociology undermine the importance of certain concepts such as habitus to explain new forms of reflexivity, the narratives gathered and the situations that I observed in Evangelista led me to ask myself about the habitus produced amongst the members of these circles regarding their academic lives: What dispositions have these girls internalised from the moral order socialised through their family and educational histories? How was it that they were able to offer a rationale for their judgments on the right and wrong ways to behave as students, sometimes aligning themselves discursively with the moral ethos of adults around them whilst simultaneously acting in contradiction to such values?

I could observe how these girls knew the norms of the school and family and knew how to play with them. Even though their opinions and actions seemed contradictory for me, they all gave reasons for all their behaviour. For example, they were all repeating and failing the school year, but they all show an understanding of the situation and what is expected of them as students and daughters. In informal conversations and interviews, they revealed that, as students, they were aware that they needed to focus on their school work, that they should attend classes, do their homework, study to pass the exams... but they failed to do so. Their excuse, especially in the final year, was the absence of their friends at the school. They all felt that their ex-classmates were off doing something new whilst they were trapped 
at school until the end of the year. When I asked them about their expectations of the future, they all claimed that they wanted to be doctors or psychologists, but none of them was willing to commit to at least four or five years of further study.

As daughters, they were aware that they should not disappoint their parents. In Carolina, Soraya and Eugenia's cases, they were aware that their parents were making efforts to better the lives of the family and "pinning their hopes" on them. However, they all failed the academic year, and in Carolina's case, having been the best student in 2B (2003/04), she got pregnant and had to drop out of school. The latter days of their academic trajectories indicated that, at the time of my fieldwork, I was witnessing the transformation of a group of schoolgirls who felt increasingly detached from their academic lives, opting to invest only in the social dimension of school (Erickson 1986). This was why their cliques were so relevant to them and why conflict between girls was taken so seriously by its protagonists. The habitus in which they were immersed and that they were reproducing valued friendship and hanging around with boyfriends more highly than investment in education, hard work or long-term plans.

Nine years after these interviews, I found their curriculums listed on job seeking websites. They were working in the service industry as saleswomen ("dependientas"). Some of the skills they highlight relate to selling, fashion and customer service (stock management, inventory, merchandise management, returns and damages).

This approach to reflexivity allows me to observe how - like identity - reflexivity itself is eminently situated. It entails the fact that, on the one hand, the reflexive operations embodied in the CNs shape and are shaped by the contextual complexities in which these narratives and acts of reflection are produced, which obliges us methodologically to bring to the fore the conditions of production of such reflexivity. On the other hand, it means that the (moral and gender) identities performed by the social actors are constructed, negotiated and associated with the contingencies of the narrated situations, and the communicative situation in which they occur.

CNs were highlighted as an important interactional genre for research into positioning and identity construction, as has been highlighted since the publication of seminal works on narrative analysis, as well as apposite communicative resources in which narrators display reflexivity. We all know their benefits as forms for gleaning evidence and lending credibility. I would like to underline their further usefulness as forms of social action that allow the researcher to look into the spaces to which we are sometimes denied access. In this case, for example, we gained access to parents' voices through the stories told and the evaluations made by their children. In later ethnographies I was able to conduct research more directly into parents' ideas and they all concurred in wanting the best for their children, in voicing the widely held belief that 'girls are more difficult and require closer control', which fits in with what Carolina reports in her testimony. 
The issues raised in this paper might be of relevance beyond research, to educators and practitioners interested in how newcomers understand and navigate new institutional norms and forms of communication. Teenagers have their own reasons to behave in the ways they do, and their positionings and behaviour signal issues important to them. Future research on case studies where students remain in hosting education systems against all odds will be necessary to understand possible factors that motivate students to continue their personal training, or discourage them from doing so, either at school or in other institutions.

\section{References}

Bakhtin, M. M. 1984. Problems of Dostoevsky's Poetics, C. Emerson (trans \& ed.). Minneapolis MN: University of Minnesota Press.

Bamberg, M. \& Georgakopoulou, A. 2008. Small stories as a new perspective in narrative and identity analysis. Text \& Talk (28): 377-396. doi:10.1515/TEXT.2008.018

Baynham, M. 2003. Narrative in space and time: Beyond 'Backdrop'. Accounts of narrative orientation. Narrative Inquiry 13 (2): 347-366. doi: 10.1177/1461445610392135

Block, D. \& Corona, V. 2016. Intersectionality in language and identity research. In The Routledge Handbook of Language and Identity, S. Preece (ed.), 507-522. New York NY: Routledge.

Bourdieu, P. 1990. The Logic of Practice. Stanford CA: Stanford University Press.

Bucholtz, M. 1999. You da man: Narrating the racial other in the production of white masculinity. Journal of Sociolinguistics 3 (4): 443-460.

Codó, E. \& Patiño-Santos, A. 2014. Beyond language: Class, social categorisation and academic achievement in a Catalan high school. Linguistics \& Education 25: 51-63. doi:10.1016/j.linged.2013.08.002

Colectivo I.O.E. 2012. VVAA. Inserción en la escuela española del alumnado inmigrante iberoamericano. Madrid: UE, MTeI, OEI

Corona, V, Nussbaum, L. \& Unamuno, V. 2013. The emergence of new linguistic repertoires among Barcelona's youth of Latin American Origin. International Journal of Bilingual Education and Bilingualism 16 (2): 182-194. Special issue: Catalan in the 21st Century. doi: $10.1080 / 13670050.2012 .720668$

De Fina, A. 2003. Identity in Narrative: A study on Immigrant Discourse [Studies in Narrative 3]. Amsterdam: John Benjamins. doi:10.1075/sin.3

De Fina, A. \& Georgakopoulou, A. 2008a. Analysing narratives as practices. Qualitative Research 8 (3): 379-387. doi:10.1177/1468794106093634

De Fina, A. \& Georgakopoulou, A. 2011. Analyzing Narrative. Discourse and Sociolinguistic Perspectives. Cambridge: CUP. doi:10.1017/CBO9781139051255

De Fina, A. \& King, A. 2011. Language problem or language conflict? Narratives of immigrant women's experiences in the US. Discourse Studies 13 (2): 163-188.

doi: 10.1177/1461445610392135

Dietrich, L.C. 1998. Chicana Adolescents: Bitches, Ho's and Schoolgirls. Westport CT: Greenwood. 
Georgakopoulou, A. 2006b. The other side of the story: Towards a narrative analysis of narratives-in-interaction. Discourse Studies 8: 265-287. doi:10.1177/1461445606061795

Georgakopoulou, A. 2007. Small Stories, Interaction and Identities [Studies in Narrative 8]. Amsterdam: John Benjamins. doi: 10.1075/sin.8

Georgakopoulou, A. 2014. Between narrative analysis and narrative inquiry: The long story of small stories research. Working Papers in Urban Language \& Literacies 131.

Giddens, A. 1991. Modernity and Self-Identity. Self and Society in the Late Modern Age. Cambridge: Polity Press.

Holmes, J. \& Meyerhoff, M. (eds). 2003. The Handbook of Language and Gender. Malden MA: Blackwell. doi: 10.1002/9780470756942

Hurd, C.A. 2004. "Acting out" and being a "school boy": Performance in an ELD classroom. In School Connections. U.S. Mexican Youth, Peers, and School Achievement, M. A. Gibson, P. C. Gándara \& J. Peterson Koyama (eds), 63-86. New York NY: Teachers College, Columbia University.

Kohler Riessman, C. 2015. Entering the hall of mirrors: Reflexivity and narrative research. In The Handbook of Narrative Analysis, A. De Fina \& A. Georgakopoulou (eds), 219-238. Hoboken NJ: Wiley-Blackwell.

Labov, W. 1972. The transformation of experience in narrative syntax. In Language in the Inner City: Studies in the Black English Vernacular, W. Labov (ed.), 354-96. Philadelphia PA: University of Pennsylvania Press.

Martín Rojo, L. 2010. Constructing Inequality in Multilingual Schools. Berlin: Mouton de Gruyter. doi: 10.1515/9783110226645

Mendoza-Denton, N. 2008. Homegirls: Language and Cultural Practice among Latina Youth Gangs. Malden MA: Blackwell. doi:10.1002/9780470693728

Newman, M., Patiño-Santos, A. \& Trenchs-Parera, M. 2013. Linguistic integration of Latin American immigrants in Catalonia and their responses to the implementation of educational language policies. International Journal of Bilingual Education and Bilingualism 16: 195-209.

Ochs, E. \& Capps, L. 2001. Living Narrative. Creating Lives in Everyday Storytelling: Cambridge MA: Harvard University Press.

Patiño-Santos, A. 2009. Narrando el conflicto: Alumnado de origen inmigrante en un centro escolar de Madrid (Narrating Conflict: Students of Immigrant Backgrounds in a School of Madrid). Discurso y Sociedad 3 (1): 119-149.

Patiño-Santos, A. 2011a. Negotiating power relations and ethnicity in a sociolinguistic ethnography in Madrid. Journal of Language, Identity and Education 10 (3): 145-163.

doi: $10.1080 / 15348458.2011 .585305$

Patiño-Santos, A. 2011b. La construcción discursiva del fracaso escolar: Una etnografía sociolingüística crítica en un centro educativo de Madrid (The discursive construction of school failure: A critical ethnographical sociolinguistics in a school in Madrid. Spanish in Context 8 (2): 235-256. doi: 10.1075/sic.8.2.03pat

Patiño-Santos, A. 2015. On Being a Latin American in La Sagrada Familia: the Negotiation of Identities and the Construction of Authenticity. In A Sociolinguistics of Diaspora: Latino Practices, Identities and Ideologies, R. Márquez Reiter, \& L. Martín Rojo (eds), 102-121. Abingdon: Routledge.

Patiño-Santos, A. Forthcoming. "No-one told me it would all be in Catalan!" - Narratives and language ideologies in the Latin American community at School. International Journal of the Sociology of Language. Special issue: Storytelling in Globalized Spaces: A Linguistic Ethnographic Perspective, A. Patiño-Santos \& A. M. Relaño-Pastor (eds). 
Reay, D. 2004. It's all becoming a habitus: Beyond the habitual use of habitus in educational research. British Journal of Sociology of Education 25 (4): 431-444.

doi: $10.1080 / 0142569042000236934$

Relaño-Pastor, M. \& De Fina, A. 2005. Contesting social place: Narratives of language conflict. In Dislocations, Relocations, Narratives of Displacement, M. Baynham \& A. De Fina (eds), 36-60. Manchester: St Jerome.

Rettis, J. 2004. Tendencias en la representación de los inmigrantes latinoamericanos en la prensa nacional española. Colombianos, ecuatorianos y argentinos: ¿iguales o diferentes? Barcelona: Paper presentado en el Forum de las Culturas.

Rymes, B. R. 2001. Conversational Borderlands: Language and Identity in an Alternative Urban High School. New York NY: Teachers College Press.

Rymes, B. 2014. Communicating Beyond Language: Everyday Encounters with Diversity. New York NY: Routledge.

Schiffrin, D. 1996. Narrative as self portrait: Sociolinguistic constructions of identity. Language in Society 25: 167-203. doi:http://dx.doi.org/10.1017/So047404500020601

Thornborrow, J. \& Coates, J. 2005. The sociolinguistics of narrative. Identity, performance, culture. In The Sociolinguistics of Narrative [Studies in Narrative 6], J. Thornborrow \& J. Coates (eds), 1-16. Amsterdam: John Benjamins. doi:10.1075/sin.6.01tho

van Dijk, T. A. 1993. Stories and racism. In Narrative and Social Control: Critical Perspectives, D. K. Mumby (ed.), 121-42. Newbury Park CA: Sage. doi:10.4135/9781483345277.n6

Vásquez, C. 2007. Moral stance in the workplace narratives of novices. Discourse Studies 9 (5): 653-675. doi: $10.1177 / 1461445607081270$

Vigil, J. D. 1988. Barrio Gangs: Street Life and Identity in Southern California. Austin TX: University of Texas Press.

Wortham, S. 2001. Narratives in Action. New York NY: Teachers College Press.

\section{Symbols used in transcripts}

PART: participant

A (Capital letters) loud talking

aa lengthening of vowel or consonant sound

/ short pause ( 0.5 seconds)

// long pause (0.5-1.5 seconds)

(( )) incomprehensible fragment

? question

- $\quad$ self interruption

\& latched utterances $=\quad$ continuation of utterance after overlapping

$\downarrow \quad$ descending intonation

$\uparrow \quad$ rising intonation

$\rightarrow$ continuing intonation

[ ] turn overlapping with similarly marked turn

Eng: fragment in English

Ital direct speech 